\title{
Prenuptial Dental Extractions in Acadian Women: First Report of a Cultural Tradition
}

\author{
Sara C. Gordon, D.D.S., M.Sc., Linda M. Kaste, D.D.S., M.S., Ph.D., ${ }^{2}$ \\ Andrei Barasch, D.M.D., MDSc, ${ }^{3}$ Monika M. Safford, M.D., W. Choong Foong, Ph.D., \\ and Adry ElGeneidy, B.D.S., D.O.S., M.Sc.D., D.Sc.D., D.D.S. ${ }^{5}$
}

\begin{abstract}
Background: Prenuptial tooth extractions, extractions of all teeth in at least one dental arch before marriage, are not identified in the dental literature. Driven by a professional encounter, the purpose of this study was to confirm the existence of this practice among Acadian women.

Methods: An 8-item survey instrument with space for comments was mailed to 182 dentists from traditionally Acadian regions of Canada. The survey was provided in English and French.

Results: Ninety dentists responded (50.3\%); 8 of them (9\%) had been asked to perform prenuptial extractions, and an additional 9 volunteered awareness of this practice. Awareness and requests were associated with dental practice in a county with a $\geq 20 \%$ French-speaking population.

Conclusions: Prenuptial extractions in this population have been confirmed by the current cohort of dentists. The potential public health, clinical, and systemic health research implications for women who are edentulous for most of their adult life merit further study. Additionally, it is important to determine if interventions are needed to curtail cultural expectations of such practices.
\end{abstract}

\section{Introduction}

$\mathrm{O}$ NE OF THE AUTHORS (S.C.G.), practicing dentistry in Nova Scotia, Canada, refused a 23-year-old woman's request to extract all her relatively healthy teeth. The woman indicated that dentures were a traditional dowry for young women in her French Acadian community. Consequently, the author wondered whether other dentists in Acadian areas of Canada shared this experience.

The Acadian community has history and culture distinct from others in Canada. The ancestors of the Acadians originally migrated from France to North America in the early 1600s. The British expelled most of them from this region between 1755 and 1762. Many relocated to portions of what became the Eastern and Southern United States of America, where they became known as Cajuns. Other Acadians escaped the forcible deportation, maintaining strong cultural traditions to this day, including their French dialect. ${ }^{1}$ However, Acadian is not synonymous with French-Canadian, and Acadian culture is different from that of nearby Francophone
Quebec. The Acadian population speaks Acadian French, although English-French bilingualism is very common. Even within counties identified as having high Acadian concentrations, the predominant language is sometimes English, not French.

We propose the term "prenuptial extractions" to describe extractions of all teeth in at least one (upper or lower) jaw before marriage, usually in a woman. No references were identified in the dental or medical literature by means of a PubMed search. A single report from Eastern Guatemala in the social sciences literature describes such a practice performed as kindness in a society where dental pain is the norm. ${ }^{2}$ Interestingly, this phenomenon in Quebec, Canada, was mentioned in the memoir Charlevoix County, 1930, by Jori Smith, where it is described as a pragmatic and esthetic choice:

When a girl was about to marry, her few remaining teeth would routinely be pulled out, and, as a wedding present, she would be given a set of false teeth. If, by some rare stroke of

\footnotetext{
${ }^{1}$ Department of Oral Medicine and Diagnostic Sciences and Department of Pathology and ${ }^{2}$ Department of Pediatric Dentistry, University of Illinois, Chicago, Illinois.

${ }^{3}$ Department of Dental Medicine, Winthrop University Hospital, Mineola, New York.

${ }^{4}$ Department of Medicine, Division of Preventive Medicine, University of Alabama, Birmingham, Alabama.

${ }^{5}$ Department of Biomedical and Diagnostic Sciences, University of Detroit Mercy, Detroit, Michigan.
} 
fortune, the future bride's teeth were still healthy, they would be removed anyway, so great was the prestige of store-bought teeth. ${ }^{3}$

Although little documentation of gender-based extractions is found in the literature, there are reports of deliberate culturally based tooth modifications. Extraction of incisors in South Africa is thought to be associated with "race and social class." ${ }^{4}$ Removal of deciduous tooth buds has been reported in Africa or elsewhere in children of African parents, performed by village healers for prevention of what were thought to be "tooth worms." ${ }^{5-7}$ Alterations to the shape of erupted teeth in skeletal remains have been reported in Guam, ${ }^{8}$ India, ${ }^{9}$ and Scandinavia. ${ }^{10}$ Tooth extraction patterns were related to social identity in prehistoric Japan. ${ }^{11}$

The purpose of this study was to explore whether dentists in Acadian regions of the Canadian provinces of New Brunswick (NB), Nova Scotia (NS), and Prince Edward Island (PEI) had encountered requests for prenuptial extractions in women. Such a tradition, if experienced by current population cohorts, could have important public health, women's health, clinical, and research implications.

\section{Materials and Methods}

The study was approved by Institutional Review Boards at University of Detroit Mercy School of Dentistry and University of Illinois at Chicago.

Counties with high Acadian concentrations were identified by consultation with Maurice Basque, Director of Acadian Studies at the University of Moncton (personal communication). The choice of counties was further verified by official data on predominant language in the area studied.,12 Dentists in those counties were identified from membership lists of the NB, NS, and PEI dental associations. In early 2004, all dentists in these counties were contacted by mail, using a modified Dillman's Tailored Design Method. ${ }^{13}$ Mailings consisted of an advance notice, one mailing of the survey with cover letter, and two postcard reminders, written in both Canadian French and English. The survey was anonymous, and prepaid return envelopes and the questionnaires were de-identified to maintain responder's anonymity. The survey instrument had 8 multiple-choice questions and a designated space for comments.

A French language density threshold was chosen, and each of the surveyed counties was dichotomized as $<20 \%$ Frenchspeaking or $\geq 20 \%$ French-speaking (Fig. 1). This was performed with information regarding the counties and their predominant language as designated by the Canadian National Francophone Economic Development Network. ${ }^{14}$ All counties surveyed in NB had $\geq 20 \%$ French speakers; in NS, half of the surveyed counties had $\geq 20 \%$ French speakers; and none of the counties of PEI had $\geq 20 \%$ French speakers.

\section{Results}

The membership lists yielded 182 dentists, who were sent mailings; 3 dentists were no longer at the listed addresses, and 90 dentists responded, yielding an adjusted response rate of $50.3 \%$.

Overall, $9 \%$ of respondents had been asked by a female to perform prenuptial extractions (Table 1): 13\% of surveyed dentists in NB, $5 \%$ in NS, and $4 \%$ in PEI (Fig. 1). Nine dentists

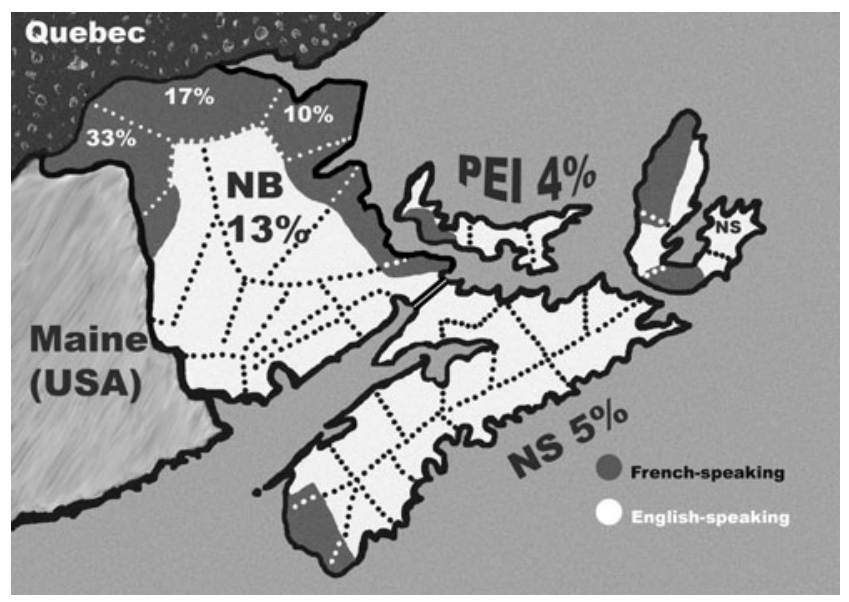

FIG. 1. This map of the eastern Canadian provinces surveyed indicates the predominant language distributions and the percentage of dentists who reported being asked to perform prenuptial extractions. Dotted lines indicate county boundaries, and the three counties with the highest reported rates of prenuptial extraction requests are seen in northern New Brunswick. NB, New Brunswick; NS, Nova Scotia; PEI, Prince Edward Island.

volunteered comments, indicating awareness of this practice, although they had not been asked to perform it themselves. One dentist described his role against this practice: "I am one of the pioneers who changed this practice of dentistry in my county. I am sure that certain dentists still perform it." [translated from French] Another dentist shared the story of her mother, whose teeth were extracted at age 16 when she briefly joined a convent, then changed her mind and married: "Dentures were a dowry for marriage. All her sisters also were edentulous when they got married." [translated from French] Four dentists mentioned the practice in groups outside the Acadian region: all four considered it a French-Canadian or Quebec practice, and one also reported it as a practice in Great Britain "because someone was coming to the 'colonies' [Canada] and might not have access to dentists." An additional dentist commented about early extractions but did not link it to marriage: "It might be interesting to know that 10 to $25 \%$ of Acadian female patients had their upper teeth only removed for esthetic reasons before they were 25 years old, in the ones who are 50 and over." [translated from French]

Eight dentists commented that they were previously unaware of this practice. An example is: "At first I thought this was a bad joke and realized you were serious. I am Acadian myself and have never heard anything like this!" Six dentists mentioned that in their communities, completely edentulous patients often see denturists for fabrication of new dentures, rather than dentists. At least one dentist reported having no edentulous patients.

Dentists were significantly more likely to be aware of prenuptial extractions $(p=0.009)$, but not significantly more likely to have been asked to perform them, if they practiced in a county with $\geq 20 \%$ French speakers. All dentists who volunteered awareness of this practice were from counties with $\geq 20 \%$ French speakers. Only one county with $\geq 20 \%$ French speakers had no respondent who indicated awareness of this practice. 
Table 1. Dentists' Experience and Awareness of Prenuptial Extraction Practice, by Province, County, and French-Speaking Population Level

\begin{tabular}{|c|c|c|c|c|c|c|}
\hline $\begin{array}{l}\text { Province } N \\
\text { (\% of respondents) }\end{array}$ & $\begin{array}{l}\text { County (responses for } \\
\text { the county include dentists } \\
\text { who reported practice } \\
\text { in more than one county) }\end{array}$ & $\begin{array}{l}\geq 20 \% \text { of } \\
\text { population } \\
\text { French- } \\
\text { speaking }\end{array}$ & $\begin{array}{l}\text { Was asked } \\
\text { to perform } \\
\text { Prenuptial } \\
\text { Extraction }\end{array}$ & $\begin{array}{l}\begin{array}{c}\text { Never } \\
\text { asked }\end{array} \\
\text { to perform } \\
\text { Prenuptial } \\
\text { Extraction }\end{array}$ & $\begin{array}{l}\text { Never asked } \\
\text { to perform } \\
\text { and aware } \\
\text { of practice } \\
\text { (by comment) }\end{array}$ & $\begin{array}{l}\text { Never asked } \\
\text { to perform } \\
\text { and not aware } \\
\text { of practice } \\
\text { (by comment) }\end{array}$ \\
\hline $\begin{array}{l}\text { New Brunswick } 45 \\
\quad(50 \%)^{\mathrm{a}}\end{array}$ & $\begin{array}{l}\text { Restigouche (6) } \\
\text { Madawaska }^{\text {b }}(7) \\
\text { Gloucester (10) } \\
\text { Kent }^{\mathrm{c}}(3) \\
\text { Victoria }^{\mathrm{b}}(4) \\
\text { Westmoreland }^{\mathrm{c}}(18) \\
\text { NB total }\end{array}$ & $\begin{array}{l}\text { Yes } \\
\text { Yes } \\
\text { Yes } \\
\text { Yes } \\
\text { Yes } \\
\text { Yes }\end{array}$ & $\begin{array}{l}1 \\
2^{\mathrm{b}} \\
1 \\
0 \\
2^{\mathrm{b}} \\
1 \\
6^{\mathrm{c}}(13 \%)\end{array}$ & $\begin{array}{l}5 \\
4 \\
9 \\
3^{\mathrm{c}} \\
2 \\
16^{\mathrm{c}} \\
39^{\mathrm{C}}(82 \%)\end{array}$ & $\begin{array}{l}2 \\
1 \\
1 \\
0 \\
0 \\
2 \\
6\end{array}$ & $\begin{array}{l}0 \\
0 \\
0 \\
1 \\
0 \\
3 \\
4\end{array}$ \\
\hline $\begin{array}{l}\text { Prince Edward Island } \\
25(27.8 \%)\end{array}$ & $\begin{array}{l}\text { Prince (5) } \\
\text { Queens (16) } \\
\text { Kings (4) } \\
\text { PEI total }\end{array}$ & $\begin{array}{l}\text { No } \\
\text { No } \\
\text { No }\end{array}$ & $\begin{array}{l}1 \\
0 \\
0 \\
1(4 \%)\end{array}$ & $\begin{aligned} 4 \\
16 \\
4 \\
24(96 \%)\end{aligned}$ & $\begin{array}{l}0 \\
0 \\
0 \\
0\end{array}$ & $\begin{array}{l}0 \\
0 \\
2 \\
2\end{array}$ \\
\hline Nova Scotia 20 (22.2\%) & $\begin{array}{l}\text { Richmond (3) } \\
\text { Inverness (4) } \\
\text { Antigonish (6) } \\
\text { Yarmouth (4) } \\
\text { Digby (3) } \\
\text { NS total }\end{array}$ & $\begin{array}{l}\text { Yes } \\
\text { No } \\
\text { No } \\
\text { Yes } \\
\text { Yes }\end{array}$ & $\begin{array}{l}0 \\
0 \\
1 \\
0 \\
0 \\
1(5 \%)\end{array}$ & $\begin{array}{l}3 \\
4 \\
5 \\
4 \\
3 \\
19(95 \%)\end{array}$ & $\begin{array}{l}1 \\
0 \\
0 \\
1 \\
1 \\
3\end{array}$ & $\begin{array}{l}0 \\
1 \\
1 \\
0 \\
0 \\
2\end{array}$ \\
\hline Total $90^{\mathrm{a}}$ & & & $8(9 \%)$ & $80(89 \%)$ & 9 & 8 \\
\hline
\end{tabular}

${ }^{a}$ Two dentists from Westmorland County, NB, did not answer the question on prenuptial extraction experience.

${ }^{b}$ One dentist practiced in both Victoria and Madawaska Counties of NB (number reflects counting both locations in county but only once in Province total).

${ }^{\mathrm{c}}$ Two dentists practiced in both Westmorland and Kent Counties of NB (number reflects counting both locations in county but only once in Province total)

\section{Discussion}

Prenuptial extractions, previously not found in the dental and medical literature, have been occurring in the contemporary Acadian population. Dentists practicing in Acadian regions of the Canadian provinces of NB, NS, and PEI have been asked at some point in their careers to perform prenuptial extractions in young women, indicating recent or current use of the practice. Additionally, dentists who had not been asked to perform these extractions were aware of the practice. The survey did not specifically ask respondents if they were aware of the practice, so this information was volunteered only by those who chose to comment upon their awareness. Other dentists may have been aware but did not mention it. Similarly, some dentists volunteered that they had never heard of prenuptial extractions, so this observation too may be underreported. Additional assessments are needed to capture whether dentists acquiesce to such requests, to explore the reasons behind this traditional practice, and to clarify the potential ties to Acadian, Francophone, or other population groups, including males.

Limited data were found on edentulism in this region. Canadian national estimates from 2003 show approximately $9 \%$ of Canadians over age 15 were completely edentulous. Complete edentulism was more common in Canadian women $(10 \%)$ than in men $(7 \%)^{15}$; unfortunately, regional gender estimates were not reported. The regions of Canada surveyed in this study are not considered to be remote areas or underserved in the provision of dental care. Interestingly, the overall edentulism rate in PEI $(7 \%)$ was below the national average, NS (10\%) was about at the national average, and NB $(12 \%)$ was above it. This order is consistent with the intensities of the dentists receiving prenuptial extraction requests and awareness of the practice found in this study.

"A tooth per child" is an adage reflecting a social perception of the cost of pregnancy to the mother's dentition. ${ }^{16} \mathrm{Re}-$ cent reports provide evidence that there may be some truth to this proverb. The evidence that women may suffer a disproportionate amount of dental disease spans the time from the introduction of agriculture ${ }^{17}$ until the present day, whether in a developing country ${ }^{18}$ or in a developed one. ${ }^{19,20}$ A number of mechanisms have been proposed for observed gender differences in oral health, most with a tie to pregnancy. ${ }^{17,21-23}$ Larsen $^{24}$ suggests that in the American southeast, dental caries in posterior teeth increased when the indigenous population shifted from subsistence foraging to an agricultural lifestyle. Larsen also points out that the increase in caries that accompanied greater access to plant carbohydrates was more pronounced in women. Lukacs ${ }^{25,26}$ similarly demonstrates a substantial increase in dental caries in women, as compared to men, accompanying intensification of agriculture in some, but not all, parts of the world and suggests a link to gender differences in food consumption and preparation. Lukacs ${ }^{27}$ also suggests this increased caries experience may be further intensified by hormonally related changes in eating patterns, salivary composition, and salivary flow rates and that increases in dental caries in women may be explained in part by increased fertility associated with the shift to an agricultural society. On the other hand, Temple ${ }^{28}$ examined dental caries among Japanese foragers between 4000 and 2300 BP and 
concluded that although women had significantly more carious molars than men, "reproductive factors played a minor role in dental caries variation between males and females" because caries variation between regions of differing population density was limited. Although a proverb may not have scientifically based origins, community observations of oral health problems associated with pregnancy or with dietary differences could potentially have provided an original motive for the tradition of prenuptial extractions.

The consequences of such a tradition merit concern. In addition to their function in eating, healthy teeth also serve as tools, as weapons, in speech, and as a sign of youth. Longterm edentulism causes loss of the height of alveolar bone $\mathrm{e}^{29,30}$ and, consequently, loss of the vertical dimension of the lower face, mandibular prognathism, and a dished-in face, ${ }^{30}$ which collectively cause a prematurely aged appearance and potential negative self-image. Loss of teeth is associated with poor nutrition, particularly a lower intake of fruits and vegetables $^{29,31}$; edentulous patients thus may have an inadequate intake of fiber and nutrients ${ }^{32}$ that are important for the maintenance of healthy digestive, circulatory, immune, and other functions. Edentulism has been associated with type 2 diabetes mellitus, ${ }^{33}$ obesity, ${ }^{34}$ coronary artery atherosclerosis, and some cancers. ${ }^{35}$ Edentulous and partly edentulous aged patients are more likely to exhibit cardiovascular risk factors ${ }^{36}$ and have a higher risk of mortality. ${ }^{37,38}$ The emotional effects of tooth loss potentially can have a "profound impact on the lives of some people, even those who are apparently coping well with dentures," according to Fiske et al. ${ }^{39}$

Dentures are no panacea. In one study, increased ridge resorption was significantly correlated with the number of years that women (but not men) are edentulous. ${ }^{29}$ Ill-fitting dentures are more common with increased bone loss ${ }^{29,30}$ and can cause trauma, mucositis, angular cheilitis, epulis fissuratum, and ulcerations. ${ }^{30,40,41}$ Candida infections are increased with dentures and with poor nutrition, ${ }^{41,42}$ and inadequate dentures can interfere with speech. ${ }^{43}$

Could edentulism be associated with an improvement in any health parameters? In view of the marked disadvantages of edentulism, it seems unlikely but may merit future exploration. A number of recent reviews have examined potential links between dental diseases (in particular, periodontitis) and various systemic conditions. ${ }^{44-48}$

Atherosclerosis is a leading cause of death in Western society, and systemic inflammation plays a role in its development. There is mounting evidence for a link between periodontal disease and atherosclerosis, including increased antibody levels against typical periodontal pathogens in patients suffering myocardial infarction; increased levels of inflammatory biomarkers, such as C-reactive protein, fibrinogen, and inflammatory cytokines, in periodontal patients; and the ability of periodontal bacteria to promote platelet aggregation and atherosclerosis. ${ }^{49,50}$ Moreover, treatment of significant periodontal disease can decrease the level of systemic inflammatory biomarkers, ${ }^{49}$ as can extraction of periodontally diseased teeth, ${ }^{51}$ although the risk for subsequent atherosclerotic complications may not be reduced. ${ }^{52}$ A recent cardiology and periodontology consensus concluded that "a direct causal relation between periodontitis and atherosclerotic CVD [cardiovascular disease] is not established." ${ }^{\prime 9}$ The consensus points out that periodontal disease and atherosclerosis share a number of common risk factors, the most important of which is smoking, but also in- cluding types 1 and 2 diabetes mellitus, obesity, unfavorable lipid profiles, and hypertension. ${ }^{49}$

Clearly, it is important to resolve a potential causal role of periodontal disease in the development of CVD and what role, if any, edentulism might play. A woman who becomes edentulous in early adulthood would not have the opportunity to develop significant periodontal disease but may suffer a number of other deleterious health effects. As illustrated by a recent report showing different immunoglobulin G (IgG) levels between edentulous and dentate adults, ${ }^{53}$ a population rendered edentulous at a young age could present an opportunity for studying the role of teeth on other systemic parameters, such as CVD. Such persons may be distinct in their immune responses compared to patients who have been challenged by dentally related infections through adulthood.

This study was hypothesis-generating in its intent, not hypothesis-testing, and served its purpose in establishing the veracity of this practice. No age, gender, language, specialty, or dental school information was collected on the dentists surveyed. Collecting these data in future studies may lead to insights on factors that make a patient comfortable about recounting an early extraction history, as well as supporting dentistry's recognition of the need for edentulous patients who see denturists for denture fabrication to also see dentists for maintenance of complete oral health. Any future study of edentulism in this region would benefit by including denturists, who are licensed to fabricate removable dentures for patients but do not perform diagnostic, preventive, or surgical services. An additional method of verifying this practice could entail examination of skeletal remains of Acadian ancestors to see if gender-based differences in dental caries and edentulism are present.

A gender-specific practice of extraction of all teeth in preparation for marriage has been identified in a specific population in Eastern Canada. Some women in Acadian regions of Atlantic Canada have approached dentists to extract all their teeth before their wedding. The practice appears to be uncommon, but dentists who practice in areas that have high French-language density are most likely to have experienced such a request. Although culturally linked tooth modifications are reported elsewhere, this specific practice has not been described previously in the medical or dental literature. It may be a present or historical practice in other population groups worldwide and has consequences for health research and for women's dental, emotional, and overall health.

\section{Acknowledgments}

We acknowledge the contributions of Julie Vecchio, University of Illinois at Chicago, and Grace Fendick for administrative assistance; Marie-Lise Shams, University of Detroit Mercy, for providing French translation of the survey; Rachel Wadley, dental student at University of Illinois at Chicago, for assistance with graphics; and Maurice Basque, University of Moncton, for providing advice on Acadian populations. This study was completed with the assistance of a faculty research grant from University of Detroit Mercy School of Dentistry. Portions of this work were presented as posters at the American Academy of Oral Medicine (AAOM) (Gordon SC, Barasch A, Foong WC, ElGeneidy AK, Safford MM. Dental disease in Acadian women. AAOM 2004, Las Vegas, NV) and the Fourth American Dental Educators Association (ADEA) 
International Women's Leadership Conference (Gordon SC, Barasch A, Safford MM, Kaste LM, Foong WC, ElGeneidy AK. Toothless brides: Prenuptial extractions in Acadian Canada. Poster. Fourth ADEA International Women's Leadership Conference 2010, Salvador, Brazil).

\section{Disclosure Statement}

The authors have no conflicts of interest to report.

\section{References}

1. Chaisson PA, Landry N. History of Acadia. The Canadian Encyclopedia. Toronto, ON, Canada: Historica Foundation, 2011. Available at www.thecanadianencyclopedia.com Accessed September 8, 2011

2. Hunter JM, Arbona SI. The tooth as a marker of developing world quality of life: A field study in Guatemala. Soc Sci Med 1995;41:1217-1240.

3. Smith J. Charlevoix County, 1930. Manotick, ON, Canada: Penumbra Press, 1998:56.

4. Friedling LJ, Morris AG. The frequency of culturally derived dental modification practices on the Cape Flats in the Western Cape. SADJ 2005;60:97,99-102.

5. Longhurst R. Infant oral mutilation. Br Dent J 2010;209: 591-592.

6. Longhurst R. IOM awareness. Br Dent J 2010;208:198.

7. Edwards PC, Levering N, Wetzel E, Saini T. Extirpation of the primary canine tooth follicles: A form of infant oral mutilation. J Am Dent Assoc 2008;139:442-450.

8. Ikehara-Quebral R, Douglas MT. Cultural alteration of human teeth in the Mariana Islands. Am J Phys Anthropol 1997;104:381-391.

9. González EL, Pérez BP, Sánchez JA, Acinas MM. Dental aesthetics as an expression of culture and ritual. Br Dent J 2010;208:77-80.

10. Arcini C. The Vikings bare their filed teeth. Am J Phys Anthropol 2005;128:727-733.

11. Temple DH, Kusaka S, Sciulli PW. Patterns of social identity in relation to tooth ablation among prehistoric Jomon foragers from the Yoshigo site, Aichi prefecture, Japan. Int J Osteoarchaeol 2011;21:323-335.

12. Natural Resources Canada. The atlas of Canada-Mother tongue 2006. Ottawa, ON, Canada: Natural Resources Canada, 2011. Available at atlas.nrcan.gc.ca/auth/english/maps/ peopleandsociety/lang/languages2006/MotherTongue06 Accessed September 11, 2011.

13. Dillman DA. Mail and internet surveys: The Tailored Design Method, 2nd ed. New York: John Wiley \& Sons, 2000.

14. Le Réseau de développement économique et d'employabilité de la francophonie canadienne (RDEE Canada) [The National Francophone Economic Development Network of Canada]. Socioeconomic Profiles New Brunswick. Ottawa, ON, Canada: RDEE Canada, 2011. Available at www .rdee.ca/statistique/en/nouveau-brunswick. Accessed September 11, 2011.

15. Millar WJ, Locker D. Edentulism and denture use. Health Rep 2005;17:55-58.

16. Christensen K, Gaist D, Jeune B, Vaupel JW. A tooth per child? Lancet 1998;352:204.

17. Watson JT, Fields M, Martin DL. Introduction of agriculture and its effects on women's oral health. Am J Hum Biol 2010; 22:92-102

18. Wandera M, Engebretsen IMS, Okullo I, Tumwine JK, Astrom AN. Socio-demographic factors related to periodontal status and tooth loss of pregnant women in Mbale district, Uganda. BMC Oral Health 2009;9:18.

19. Russell SL, Ickovics JR, Yaffee RA. Exploring potential pathways between parity and tooth loss among American women. Am J Public Health 2008;98:1263-1270.

20. Russell SL, Ickovics JR, Yaffee RA. Parity and untreated dental caries in U.S. women. J Dent Res 2010;89:1091-1096.

21. Meisel P, Reifenberger J, Haase R, Nauk M, Bandt C, Kocher $\mathrm{T}$. Women are periodontally healthier than men, but why don't they have more teeth than men? Menopause 2008; 15:270-275.

22. Grant WB. High vitamin D and calcium requirements during pregnancy and tooth loss. Am J Public Health 2008; 98:1931-1932.

23. Lukacs JR. Fertility and agriculture accentuate sex differences in dental caries rates. Curr Anthropol 2008;49:901-914.

24. Larsen CS. Gender, health, and activity in foragers and farmers in the American southeast: Implications for social organization in the Georgia Bight. In: Grauer AL, StuartMacadam P, eds. Sex and gender in paleopathological perspective. Cambridge, UK: Cambridge University Press, 1998: 165-175.

25. Lukacs JR. Sex differences in dental caries experience: Clinical evidence, complex etiology. Clin Oral Invest 2010. [Epub ahead of print] Available at www.springerlink.com.proxy .cc.uic.edu/content/k3t0643r47556414/fulltext.html Accessed September 11, 2011.

26. Lukacs JR. Gender differences in oral health in South Asia: Metadata imply multifactorial biological and cultural causes. Am J Hum Biol 2011;23:398-411.

27. Lukacs JR. Sex differences in dental caries rates with the origin of agriculture in South Asia. Curr Anthropol 1996; 37:147-153.

28. Temple DH. Variability in dental caries prevalence between male and female foragers from the late/final Jomon period: Implications for dietary behavior and reproductive ecology. Am J Hum Biol 2011;23:107-117.

29. Narhi TO, Ettinger RL, Lam EWM. Radiographic findings, ridge resorption, and subjective complaints of complete denture patients. Int J Prosthodont 1997;10:183-189.

30. Allen PF, McMillan AS. A review of the functional and psychosocial outcomes of edentulousness treated with complete replacement dentures. J Can Dent Assoc 2003;69:662.

31. Brennan DS, Singh KA, Liu P, Spencer AJ. Fruit and vegetable consumption among older adults by tooth loss and socio-economic status. Aust Dent J 2010;55:143-149.

32. Nowjack-Raymer RE, Sheiham A. Association of edentulism and diet and nutrition in U.S. adults. J Dent Res 2003;82: 123-126.

33. Cleary TJ, Hutton JE. An assessment of the association between functional edentulism, obesity, and NIDDM. Diabetes Care 1995;18:1007-1009.

34. Österberg T, Dey DK, Sundh V, Carlsson GE, Jansson JO, Mellström D. Edentulism associated with obesity: A study of four national surveys of 16416 Swedes aged 55-85 years. Acta Odontol Scand 2010;68:360-367.

35. Felton DA. Edentulism and comorbid factors. J Prosthodont 2009;18:88-96.

36. Syrjälä AMH, Ylöstalo P, Hartikainen S, Sulkava R, Knuuttila $\mathrm{M}$. Number of teeth and selected cardiovascular risk factors among elderly people. Gerodontology 2010;27:189-192.

37. Österberg T, Carlsson GE, Sundh V, Mellström D. Number of teeth-A predictor of mortality in 70-year-old subjects. Community Dent Oral Epidemiol 2008;36:258-268. 
38. Brown DW. Complete edentulism prior to the age of 65 years is associated with all-cause mortality. J Public Health Dent 2009;69:260-266.

39. Fiske J, Davis DM, Frances C, Gelbier S. The emotional effects of tooth loss in edentulous people. Br Dent J 1998; 184:90-93.

40. Peltolta P, Vehkalahti MM, Wuolijkoki-Saaristo K. Oral health and treatment needs of the long-term hospitalised elderly. Gerodontology 2004:21:93-99.

41. Carlsson GE. Clinical morbidity and sequelae of treatment with complete dentures. J Prosthet Dent 1998;79:17-23.

42. Tanaka J, Tanaka M. Influence of type of prosthesis on oral environment and the number of missing teeth in elderly persons. Int J Dent 2010. [EPub ahead of print] Available at www.hindawi.com/journals/ijd/2010/584134.html Accessed September 11, 2011.

43. Roumanas ED. The social solution-Denture esthetics, phonetics, and function. J Prosthodont 2009;18:112-115.

44. Gordon SC, Barasch A, Foong WC, ElGeneidy AK, Safford MM. Does dental disease hurt your heart? J Can Dent Assoc 2005;71:93-95.

45. Joshipura K, Zevallos JC, Ritchie CS. Strength of evidence relating periodontal disease and atherosclerotic disease. Compend Contin Educ Dent 2009;30:430-439.

46. Kebschull M, Demmer RT, Papapanou PN. "Gum bug, leave my heart alone!"-Epidemiologic and mechanistic evidence linking periodontal infections and atherosclerosis. J Dent Res 2010;89:879-902.

47. Uppal A, Uppal S, Pinto A, et al. The effectiveness of periodontal disease treatment during pregnancy in reducing the risk of experiencing preterm and low birth weight. J Am Dent Assoc 2010;141:1423-1434.
48. Matevosyan NR. Periodontal disease and perinatal outcomes. Arch Gynecol Obstet 2011;283:675-686.

49. Friedewald VE, Kornman KS, Beck JD, et al. The American Journal of Cardiology and Journal of Periodontology editors' consensus: Periodontitis and atherosclerotic cardiovascular disease. Am J Cardiol 2009;104:59-68.

50. Kerrigan SW, Cox D. The thrombotic potential of oral pathogens. J Oral Microbiol 2009. [EPub ahead of print] Available at www.ncbi.nlm.nih.gov/pmc/articles/PMC30 77004/?tool=pubmed Accessed September 11, 2011.

51. Taylor BA, Tofler GH, Carey HMR, et al. Full-mouth tooth extraction lowers systemic inflammatory and thrombotic markers of cardiovascular risk. J Dent Res 2006;85:74-78.

52. Craig RJ. Destructive periodontal diseases, systemic inflammation, and atherosclerotic complications: The emerging role of the dental profession. J Calif Dental Assoc 2009; 37:773-777.

53. Vlachojannis C, Dye BA, Herrera-Abreu M, et al. Determinants of serum IgG responses to periodontal bacteria in a nationally representative sample of U.S. adults. J Clin Periodontol 2010;37:685-696.

Address correspondence to: Sara C. Gordon, D.D.S., M.Sc. Oral Medicine and Diagnostic Sciences (MC838) College of Dentistry University of Illinois at Chicago 801 South Paulina Street, Room 525B

Chicago, IL 60612

E-mail: gordonsa@uic.edu 